\title{
Influence of soil properties on crop yield: a multivariate statistical approach
}

\author{
Katalin Juhos ${ }^{1 *}$, Szilárd Szabó ${ }^{2}$, and Márta Ladányi ${ }^{3}$ \\ ${ }^{1}$ Department of Soil Science and Water Management, ${ }^{3}$ Department of Biometrics and Agricultural Informatics, \\ Corvinus University of Budapest, 29-43 Villányi St., H-Budapest, Hungary \\ ${ }^{2}$ Department of Physical Geography and Geoinformatics, University of Debrecen, 1 Egyetem tér, H-4032 Debrecen, Hungary
}

Received April 15, 2015; accepted September 29, 2015

\begin{abstract}
A b s t r a c t. The aim of the study was to reveal the relationship between soil properties and grain yields in an East Hungarian region in regard to weather conditions. Soil pH, EC, carbonate content, soluble and exchangeable $\mathrm{Na}+$, texture, organic carbon, and nutrient contents were analyzed. Yield data (maize, winter wheat, sunflower) from 10 years were standardized using calculated relativeyield and yield variability. Weatherconditions were characterized by the Pálfai Drought Index. Hydrological and topographical conditions were characterized by the mean altitude of plots. The ranged pedological variables were analyzed using principal component analysis with Varimax rotation. The principal component analysis showed that three principal components with eigenvalues greater than one explained more than $84 \%$ of the variability of soil properties. The multiple stepwise principal regression analysis showed that the mean relative yield was linearly correlated with all the three principal component factors $\left(\mathrm{R}^{2}=0.49, \mathrm{p}<0.01\right)$. In droughty years, the sodification, salinization, soil texture, and nutrient contents determined the yields $\left(\mathrm{R}^{2}=0.30, \mathrm{p}<0.05\right)$. In humid years, the lower topographical position, soil organic matter, and nutrient contents were the main limiting factors $\left(\mathrm{R}^{2}=0.40, \mathrm{p}<0.01\right)$. Consequently, the variables can effectively explain the yield variability together with other variables as linear combinations.
\end{abstract}

$\mathrm{K}$ e y w o r d s: principal component regression analysis, soilplant relationship, weather conditions

\section{INTRODUCTION}

The relationship between crop yield and soil is very complex and depends on complex interactions between physical and chemical properties of soil and other external natural factors (Sys et al., 1991). Understanding the variability of landscape and soil properties and their effect on crop yield is a critical component of site-specific and sustainable management systems and land use planning. Several statistical methods have been developed to predict

\footnotetext{
*Corresponding author e-mail: katalin.juhos@uni-corvinus.hu
}

the yields. The suitability of these methods depends on the structure and size of the database, but each method has its own limitations.

By applying stepwise multivariate linear regression analysis (SMLR), several authors have found that pedological indicators have a significant relationship with crop yield (Andrews and Carrol, 2001; Brubaker et al., 1994; De Araujo et al., 2009; Rezaei et al., 2006; Smith et al., 1993). Simple linear functions, however, are usually inappropriate to describe the effect of soil indicators on the productivity. Furthermore, intercorrelation among soil properties can result in multicollinearity problems regarding relationships between soil properties and crop yield. However, removal of some variables could contribute to losing important information.

To solve multicollinearity problems between independent variables, several authors applied partial least squares regression (PLS) (Corwin et al., 2003; Ping et al., 2004). Loadings from linear combinations of variables in PLS allowed identifying soil properties that have the greatest influence on yields. Another option is combining variables based on their linear correlation using principal component analysis (PCA). The PCA can simplify the structure of a set of variables by replacing those with a few uncorrelated linear combinations of original variables. According to Stenberg (1998), this method may produce new less interpretable combined variables. These PCA factors do not explain the total variance of the entire data set. However, several authors determined the relationships between soil attributes and yields by conducting linear multivariate regression processes with derived PCA factors as independent variables (Ayoubi et al., 2009; Cox et al., 2003; Mallarino et al., 1999; Shukla et al., 2004b).

(C) 2015 Institute of Agrophysics, Polish Academy of Sciences 
Classification and regression trees (CARTs) are more robust techniques for predicting yield variability responses to variations of soil properties and management practices due to their low prediction error (Ahman and Bhatti, 2015; Tittonell et al., 2007; Zheng et al., 2009).

In our region, a research team tried to assess the interactions of climatic, topographic, hydrological, edaphic, and management factors to determine a production process in Hungary (Tóth, 2011). The research was based on processing of the national databases relating to soil, meteorology, fertilizing, and crop yields were processed using a general linear model. They have proved that it is worth examining the soil productivity potential at the genetic soil unit level. In addition, the yield variability depends on soil attributes that affect soil moisture regime (eg texture, topographical position) and the soil nutrient supply. However, the reasons for the yield variability are still poorly understood.

According to our hypothesis, simple pedological indicators by themselves are not suitable to reveal the relationship between soil properties and crop yield. Namely, it would be difficult to find some usable equation that explains productivity. Multivariate statistical tools are necessary. The aim of this paper was to reveal the relationship between soil parameters and productivity in an East Hungarian region and to prove better performance in predictions of a potential crop yield variation in regard to different weather conditions over years.

\section{MATERIALS AND METHODS}

The research site covers approximately 225 ha and is located in East Hungary $\left(21^{\circ} 13^{\prime} 21.1^{\prime \prime}-15^{\prime} 15.5^{\prime \prime} \mathrm{E}, 47^{\circ} 17^{\prime} 5.7^{\prime \prime}\right.$ $-19^{\prime} 8.7^{\prime \prime} \mathrm{N}$ ) at an altitude of $86-89.5 \mathrm{~m}$. The site was classified as according to the Köppen climate classification (Cfa) climatic region due to warm temperate climate (Fábián and Matyasovszky, 2010) characterized by mean annual precipitation of $580 \mathrm{~mm}$ and mean annual temperature of $10.5^{\circ} \mathrm{C}$. During the 10 years studied (2004-2013), there were 4 years of drought (2007; 2009; 2012 and 2013) with less than $200 \mathrm{~mm}$ of precipitation from April to August. The years were separated into two groups according to the Pálfai Drought Index (PDI, Pálfai, 2002) (Table 1).

The depth of groundwater table is approximately $50-300 \mathrm{~cm}$. The soils developed on alluvial deposits with loam, loamy clay, and clay texture. They can be classified as Chernozems, Solonetz, and Gleysols (FAO, 2014). The agricultural management practice and crop rotation were the same on every plot. The management was characterized by conventional tillage in a nonirrigated system and nitrogen fertilization was only applied. The plot areas ranged from 1.04 to 31.90 ha (Fig. 1).

The soil survey was conducted in 2010 for analysis of physical and chemical properties that were previously considered important in land-use management in our region. Soil samples were collected at $0-100$ at $20 \mathrm{~cm}$ depth increments (Fig. 1). Soil pH was measured in a 1:2.5 soil/ $\mathrm{KCl}$

T a b l e 1. Weather conditions of years 2004-2013 including mean temperature of April-August $\left(\mathrm{T}_{\mathrm{IV}-\mathrm{VIII}}\right)$, weighted precipitation of October-August $\left(\mathrm{P}_{\mathrm{X}-\mathrm{VIII}}\right)$ and Pálfai drought index (PDI) (Pálfai, 2002)

\begin{tabular}{lccc}
\hline Year & $\left.\mathrm{T}_{\mathrm{IV}-\mathrm{VIII}}{ }^{\circ} \mathrm{C}\right)$ & Weighted $\mathrm{P}_{\text {X-VIII }}(\mathrm{mm})$ & $\mathrm{PDI}=\frac{\mathrm{T}_{\mathrm{V} \text {-VIII }}}{\mathrm{P}_{\mathrm{X} \text {-VIII }}} 100$ \\
\hline 2004 & 17.40 & 605.94 & 2.87 \\
2005 & 17.52 & 578.06 & 3.03 \\
2006 & 17.84 & 460.53 & 3.87 \\
2007 & 19.66 & 361.63 & 5.44 \\
2008 & 18.32 & 506.85 & 3.61 \\
2009 & 19.24 & 326.87 & 5.89 \\
2010 & 18.26 & 755.36 & 2.42 \\
2011 & 18.56 & 552.99 & 3.36 \\
2012 & 19.48 & 243.66 & 7.99 \\
2013 & 18.84 & 309.19 & 6.09 \\
Mean & 18.51 & 470.12 & 4.46 \\
\hline
\end{tabular}

Data source: Hungarian Meteorological Service, 2014. Boldface numbers: drought years, PDI $>5.0$. 


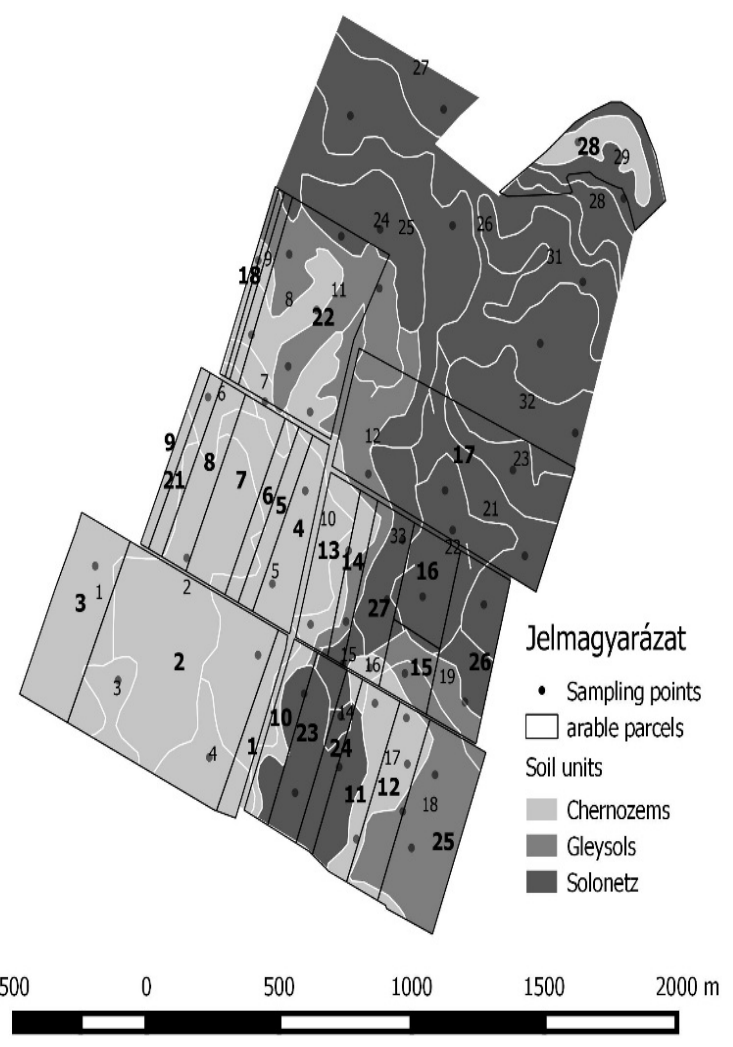

Fig. 1. Arable plots (boldface numbers) and homogeneous soil units (small normal numbers) on the research site.

mixture, and electrical conductivity (EC) in a 1:5 soil/water mixture potentiometrically. Determination of the total carbonate content $\left(\mathrm{CaCO}_{3}\right)$ was conducted according to the volumetric method (MSZ, 1978). Determination of soluble and exchangeable sodium (AL-Na) was based on extraction with acid ammonium lactate (Egnér et al., 1960). Particles smaller than $0.002 \mathrm{~mm}$ (clay) and $0.02 \mathrm{~mm}$ (clay + silt) were determined by the pipette method (MSZ, 1978). Organic carbon content (OC) was measured by the Turin method (Kononova, 1966). Homogeneous soil units were delimited based on the soil survey (Fig. 1). Mean soil properties (at 0-100 cm depth) and surface elevation were calculated for each plot. Soil samples composed of 20 subsamples were collected for analysis of potentially available nutrients at 0-30 cm depth from the 28 plots every year (2004-2013). The hydrolysable nitrogen content (ammonium- and nitrate-N and some easily available amino-N forms) was determined by oxidative hydrolysis according to Hargitai (1970) (Hargitai-N). Available phosphorous $\left(\mathrm{AL}-\mathrm{P}_{2} \mathrm{O}_{5}\right)$ and potas sium $\left(\mathrm{AL}-\mathrm{K}_{2} \mathrm{O}\right)$ contents were determined with acidic ammonium lactate extraction (Egnér et al., 1960). These annual nutrient contents were averaged. Furthermore, an average altitude of the plots was calculated since the topographical position (microrelief) determines and characterizes well the soil moisture regime and average depth of groundwater table. The spatial analysis and soil unit mapping were carried out by the software application QGIS 2.2.
Winter wheat (Triticum aestivum L.), maize (Zea mays L.), and sunflower (Helianthus annuus L.) yield data were collected at each plot from 2004 to 2013. Since the potential productivity of soil does not equal current (and actual) yields and they are also determined by other external factors, we calculated relative mean yield and yield variability indices for ten years instead of analysing the raw yield data. The data were first standardized using the relative yield of each crop calculated as follows:

$$
R Y_{p}=\frac{Y_{p}}{Y_{\max }}
$$

where: $R Y_{p}$ is the relative yield of plot $p$ (a value between 0 and 1), $Y_{p}$ - yield of plot $p\left(\mathrm{tha}^{-1}\right), Y_{\max }$ - maximum yield on the total research site over all plots $\left(\mathrm{t} \mathrm{ha}^{-1}\right)$. Then, the mean relative yields of all years, droughty years, and humid years $\left(\overline{R Y_{p}}\right)$ were calculated for each plot $p$. Yield variability was expressed as follows:

$$
C V\left(R Y_{p}\right)=\frac{S D\left(R Y_{\mathrm{p}}\right)}{\overline{R Y_{p}}} 100,
$$

where: $C V\left(R Y_{p}\right)$ is the yield variability of plot $p(\%)$, $S D\left(R Y_{p}\right)$ is the standard deviation of the relative yield of plot $p(2004-2013),\left(\overline{R Y_{p}}\right)$ is the mean relative yield of plot $p$ (2004-2013).

A principal component analysis (PCA) of the total data set of pedological variables were conducted with Varimax (orthogonal) rotation (Ayoubi et al., 2009; Cox et al., 2003; Shukla et al., 2004b). In order to obtain well interpretable PCs, the indicator values were first ranked in ascending or descendingorderusingalinearfunctiondependingonwhether a higher value was considered 'beneficial' or 'detrimental' in terms of soil function (Table 2). To mitigate the leptokurtic character of variable $\mathrm{AL}-\mathrm{P}_{2} \mathrm{O}_{5}$ and $\mathrm{CaCO}_{3}$, logarithmic (ln) transformation was conducted. The PCA was based on the linear correlation between input indicators.

With dependent variables 'mean relative yield' $\left(R Y_{p}\right)$ and 'yield variability' $\left(C V\left(R Y_{p}\right)\right)$, multiple linear regressions were conducted with a stepwise method using the derived PC factors with eigenvalues greater than 1 (Kaiser, 1960). All variables were examined as to whether there is any indication for nonlinear analysis but we did not find any reason. All data were statistically processed using IBM SPSS Statistics 20.

\section{RESULTS AND DISCUSSION}

The plots show striking differences in the yields. The mean yield of maize was $6.71 \mathrm{t} \mathrm{ha}^{-1}$ on the total arable land area, while the maximum yield was $10 \mathrm{tha}^{-1}$ on plots 17 and 21. The mean yield of winter wheat was $4.63 \mathrm{tha}^{-1}$ on the total area while the maximum yield was $7.1 \mathrm{t} \mathrm{ha}^{-1}$ on plots 3 and 5. The sunflower produced between 1.4 and $4.5 \mathrm{tha}^{-1}$ (maximum yield was found on plot 23). The mean yield of sunflower was $2.77 \mathrm{t} \mathrm{ha}^{-1}$. The plots were clearly separated into three productivity classes along the mean relative yield 
T a b l e 2. Descriptive statistics including mean, standard deviation (SD), kurtosis, skewness, and minimum and maximum values for soil physical and chemical properties of the plots $(n=28)$

\begin{tabular}{|c|c|c|c|c|c|c|c|}
\hline Variable & $\begin{array}{l}\text { Soil layer } \\
(\mathrm{cm})\end{array}$ & Mean & SD & Skewness & Kurtosis & Min & Max \\
\hline $\mathrm{pH} \downarrow$ & $0-100$ & 7.39 & 0.24 & 0.72 & 0.39 & 7.07 & 7.95 \\
\hline $\mathrm{CaCO}_{3}(\%) \uparrow$ & $0-100$ & 7.72 & 3.44 & 1.69 & $2.87 *$ & 2.86 & 18.29 \\
\hline $\mathrm{EC}\left(\mu \mathrm{S} \mathrm{cm}^{-1}\right) \downarrow$ & $0-100$ & 293.46 & 136.39 & 1.13 & -0.10 & 187.40 & 593.51 \\
\hline $\mathrm{AL}-\mathrm{Na}\left(\mathrm{mg} \mathrm{kg}^{-1}\right) \downarrow$ & $0-100$ & 69.62 & 60.66 & 1.39 & 0.67 & 23.00 & 221.59 \\
\hline Topography (altitude, m) $\uparrow$ & - & 87.68 & 0.51 & 0.40 & -0.42 & 87.01 & 88.55 \\
\hline Silt + clay $<0.02 \mathrm{~mm}(\%) \downarrow$ & $0-100$ & 44.98 & 10.61 & 0.99 & 0.61 & 31.55 & 72.36 \\
\hline Clay $<0.002 \mathrm{~mm}(\%) \downarrow$ & $0-100$ & 14.89 & 6.86 & 1.27 & 0.99 & 18.48 & 33.30 \\
\hline $\mathrm{OC}(\%) \uparrow$ & $0-100$ & 1.47 & 0.26 & -0.09 & 0.07 & 0.91 & 1.75 \\
\hline $\mathrm{AL}-\mathrm{P}_{2} \mathrm{O}_{5}\left(\mathrm{mg} \mathrm{kg}^{-1}\right) \uparrow$ & $0-30$ & 126.26 & 62.35 & 2.06 & $4.97 *$ & 72.26 & 349.25 \\
\hline $\mathrm{AL}-\mathrm{K}_{2} \mathrm{O}\left(\mathrm{mg} \mathrm{kg}^{-1}\right) \uparrow$ & $0-30$ & 259.04 & 50.40 & 0.32 & -0.58 & 160.32 & 348.85 \\
\hline Hargitai-N $\left(\mathrm{mg} \mathrm{kg}^{-1}\right) \uparrow$ & $0-30$ & 61.03 & 4.79 & -1.16 & -0.93 & 51.52 & 68.93 \\
\hline
\end{tabular}

Ranked in: $\downarrow$ descending order (less is more beneficial), $\uparrow$ ascending order (more is more beneficial), *leptokurtic character, logarithmic transformation was conducted.

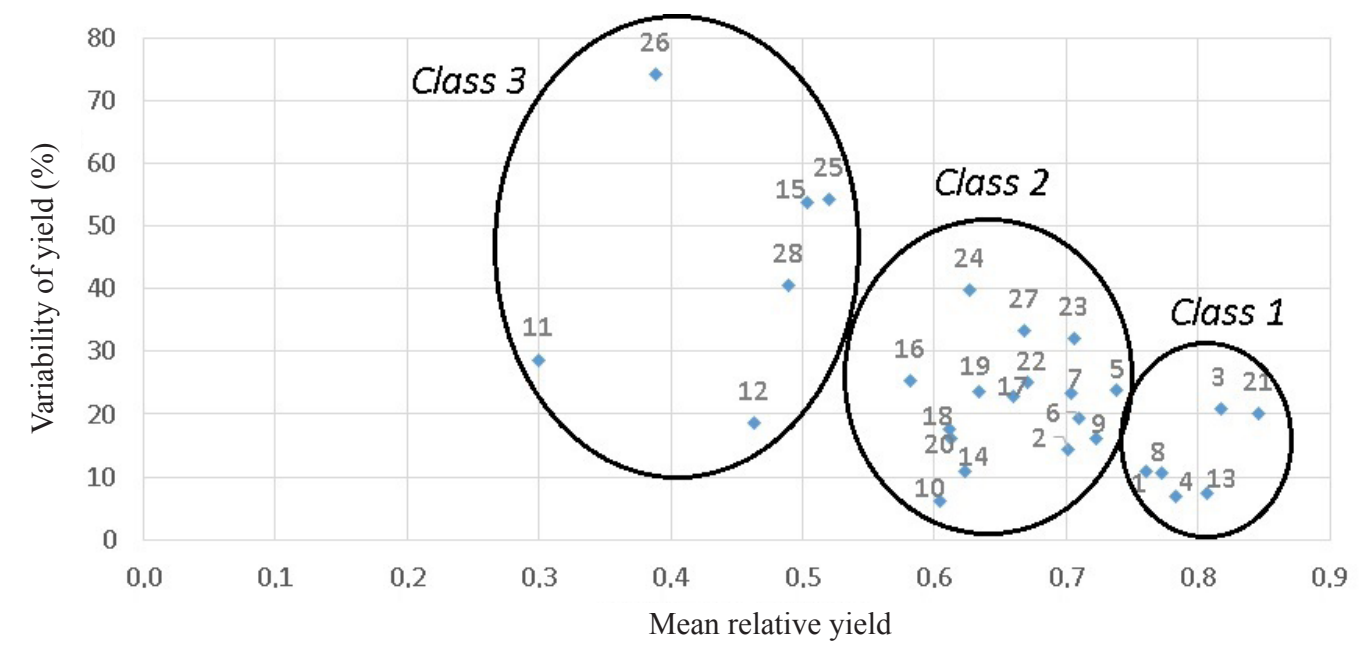

Fig. 2. Mean relative yield and variability of the yield of the plots (class 1 - low risk, class 2 - moderate risk, class 3 - high risk). Reference yield: relative yield of $1.0=$ maximum yield of 10 years (maize, winter wheat, and sunflower: $10,7.1$ and $4.5 \mathrm{t}$ ha ${ }^{-1}$, respectively).

and yield variability (Fig. 2). It seems that the highest yield and lowest variance were found on the Chernozems, the medium yield and medium variance on the Solonetz soils, and the lowest yield and highest variance on the Gleysols. Drought did not influence the yields substantially because of the high water capacity of soils (Fig. 3). However, plots with productivity class 3 had the lowest mean yield and greatest yield variability because of groundwater recharge or returning to the surface in humid years.
Therefore, it seems that any of the sodification, salinization, high clay content, and the lower topographical position might determine the yields in our study. Under the meteorological/hydrological conditions of the Hungarian Plain, arable lands are sensitive and vulnerable to salinization and extreme moisture regime stresses (Douaik et al., 2007; Tóth et al., 2001). Soil salinity and sodicity are often related to the presence of a shallow groundwater table. The low agricultural utility of salt-affected and heavy-textured 


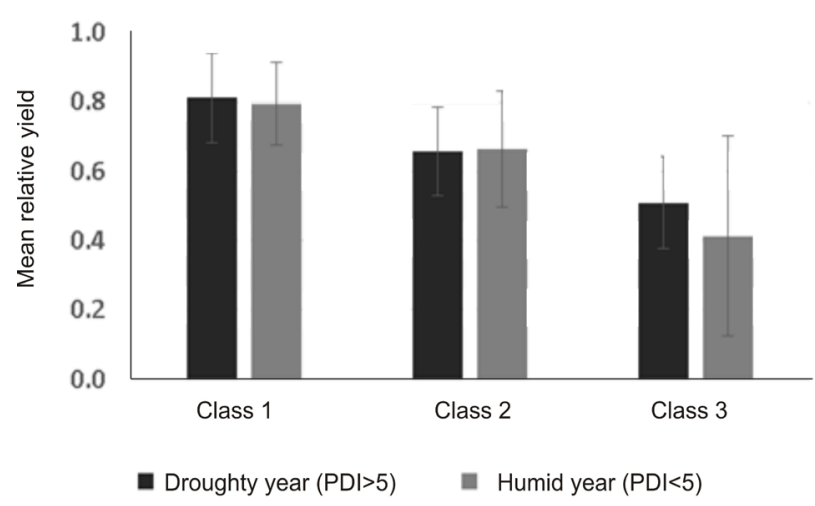

Fig. 3. The mean relative yield and standard deviation of productivity classes (PDI: Pálfai drought index).

T a b l e 3. Results of principal component analysis

\begin{tabular}{lccc}
\hline Principal components & PC1 & PC2 & PC3 \\
\hline Eigenvalues & 5.776 & 2.118 & 1.449 \\
\% of variance & 52.502 & 19.253 & 13.169 \\
$\begin{array}{l}\text { Cumulated \% of total } \\
\text { variance }\end{array}$ & 52.502 & 71.758 & 84.926
\end{tabular}

Factor loadings

\begin{tabular}{lccc}
$\mathrm{pH}$ & $\mathbf{0 . 7 3 3}$ & 0.591 & 0.275 \\
$\mathrm{EC}$ & $\mathbf{0 . 9 7 1}$ & -0.074 & -0.021 \\
$\mathrm{AL}-\mathrm{Na}$ & $\mathbf{0 . 9 7 0}$ & 0.014 & -0.062 \\
$\mathrm{CaCO}_{3}$ & 0.036 & $\mathbf{- 0 . 9 0 7}$ & -0.146 \\
$\mathrm{Silt}+$ clay $(<0.02 \mathrm{~mm})$ & $\mathbf{0 . 8 5 0}$ & 0.323 & 0.187 \\
$\mathrm{Clay}(<0.002 \mathrm{~mm})$ & $\mathbf{0 . 9 4 9}$ & 0.122 & 0.184 \\
$\mathrm{AL}-\mathrm{P}_{2} \mathrm{O}_{5}$ & -0.119 & 0.121 & $\mathbf{- 0 . 9 2 6}$ \\
$\mathrm{AL} \mathrm{K}_{2} \mathrm{O}$ & -0.043 & 0.001 & $\mathbf{- 0 . 9 2 7}$ \\
Hargitai-N & 0.428 & -0.345 & 0.315 \\
OC & 0.533 & $\mathbf{0 . 7 5 9}$ & -0.017 \\
Topography & $\mathbf{0 . 7 2 6}$ & 0.370 & 0.395 \\
\hline
\end{tabular}

Model diagnostics: $\mathrm{KMO}=0.69, \chi 2(55)=378.132 ; \mathrm{p}<0.001$, boldface loadings were considered as highly weighted in PCs.

alkali soils are closely related to their unfavourable physical and hydrophysical properties, as well as their extreme moisture regime (Várallyay, 2008). The organic carbon, available nitrogen, phosphorus, and potassium contents were very different (Table 3 ) but considered relatively high (Csathó, 2005; Németh, 2006). The soil nutrient content also depends on how long the low or high intensity farming has been in existence but the past agricultural practice were not examined in our research.

Some indicators had a significant influence on the mean relative yield of plots. Simple linear regressions led to significant models with $\mathrm{pH}, \mathrm{OC}$, and topography indicators $\left(\mathrm{R}^{2}=0.42,0.25,0.37\right)$. We did not find any reason for nonlinear analysis. Therefore, the organic carbon content might be an important soil parameter to predict yields. The relationship between soil organic matter indicators and yields was well known but described by non-linear regression using the modified Mitscherlich equation (Csathó, 2003a, b). Separate examinations of the indicators can result in false conclusions. However, having all of the simple indicators as well as the selected non-correlated indicators, multivariate stepwise regressions for mean relative yield and yield variability were all unsuccessful, namely the multiple regression models could not be reasonably interpreted. A dimension reduction by principal component analysis was necessary.

According to the eigenvalues greater than 1, the PCA yielded three principal components explaining a total of $84.926 \%$ of the variance for the entire set of variables (Table 3). Principal component 1 (PC1) was identified as salinisation, sodification, and sodium-enhanced clay translocation at a specific altitude due to the high loadings of the following items: AL-Na, EC, clay, clay + silt, $\mathrm{pH}$, and topography. The first factor accounted for $52.502 \%$ of the total variance and discriminated well the plots on Solonetz soils from the ones on Chernozems. PC2 was labelled as $\mathrm{pH}$, accumulation of calcium carbonates, and humification due to the high loadings of the following variables: $\mathrm{pH}$, $\mathrm{CaCO}_{3}$, and OC. Namely, this factor expressed the remaining basic capacity caused by the $\mathrm{CaCO}_{3}$ content and could discriminate the Calcic Gleysols with low soil organic matter from the Calcic Chernozems. The variance explained by the second factor was $19.253 \%$. PC3 was identified as available nutrient content due to the high loadings of AL- $\mathrm{P}_{2} \mathrm{O}_{5}$ and $\mathrm{AL}-\mathrm{K}_{2} \mathrm{O}$. This factor accounted for $13.169 \%$ of the total variance. The communalities of the variables included were high $(>0.82)$ with the exception of one variable (Hargitai-N) having a small amount of variance $(40.2 \%)$ in common with the other variables in the analysis. Therefore, we identified three artificial variables which are independent of one another (ie they are uncorrelated) and characterize the soil capacities on an ascending scale because of the linear scoring of indicators.

Factor analyses, especially PCA, are widely considered as suitable methods to process even highly correlated edaphic variables (Shukla et al., 2004a; Govaerts et al., 2006; Yao et al., 2013). A Varimax rotation enhances the interpretability of the uncorrelated components. The derived factors are designated as soil quality indices or complex indicators. Although these PCA factors do not explain the 
T a b l e 4. The results of the nonlinear principal component regression models: the estimated parameter and the regression diagnostics ( $F$ value of the model, Student $t$ values of the parameters, and the explained variance $\mathrm{R}^{2}$ )

\begin{tabular}{|c|c|c|c|c|c|}
\hline Dependent variable & \multicolumn{2}{|c|}{ Estimated parameters } & $t(d f=26)$ & $\mathrm{F}$ & $\mathrm{R}^{2}$ \\
\hline \multirow{4}{*}{$\overline{R Y}_{p}$ droughty years } & constant & 0.66 & $0.02 * * *$ & \multirow{4}{*}{$5.36^{*}$} & \multirow{4}{*}{0.30} \\
\hline & PC1 & 0.40 & $2.38 *$ & & \\
\hline & PC2 & \multicolumn{2}{|c|}{ excluded from the model } & & \\
\hline & PC3 & 0.38 & $2.25 *$ & & \\
\hline \multirow{4}{*}{$\overline{R Y}_{p}$ humid years } & constant & 0.64 & $0.02 * * *$ & \multirow{4}{*}{$8.47 * *$} & \multirow{4}{*}{0.40} \\
\hline & PC1 & exclu & model & & \\
\hline & $\mathrm{PC} 2$ & 0.52 & $3.34 * *$ & & \\
\hline & PC3 & 0.37 & $2.40^{*}$ & & \\
\hline \multirow{4}{*}{$R Y_{p}$ all years } & constant & 0.64 & $34.30 * * *$ & \multirow{4}{*}{$7.61 * *$} & \multirow{4}{*}{0.49} \\
\hline & PC1 & 0.36 & $2.45^{*}$ & & \\
\hline & PC2 & 0.45 & $3.04 * *$ & & \\
\hline & PC3 & 0.40 & $2.75 *$ & & \\
\hline \multirow{4}{*}{$C V\left(R Y_{p}\right)$ all years } & constant & 24.88 & $10.46^{* * *}$ & \multirow{4}{*}{$8.74 * *$} & \multirow{4}{*}{0.41} \\
\hline & PC1 & -0.45 & $-2.94 * *$ & & \\
\hline & PC2 & -0.46 & $-2.98 * *$ & & \\
\hline & PC3 & \multicolumn{2}{|c|}{ excluded from the model } & & \\
\hline
\end{tabular}

Significant at: $* \mathrm{p}<0.05, * * \mathrm{p}<0.01, * * * \mathrm{p}<0.001$.

total variance of the entire set of variables, PCA is considered as a reasonable dimension reduction method and the PC factors can be well interpreted.

The linear multiple PCR for the mean relative yield of all years $\left(\overline{R Y_{p}}\right)$ selected all the three PC factors into the linear model, so the explained variance was as $\mathrm{R}^{2}=0.49$ $(\mathrm{p}<0.01)$ (Table 4). The $\mathrm{F}$ test resulted in a significant model and the coefficients of the PC1, PC2, and PC3 factors together with the constant were all significant. The PCR for the mean relative yield of droughty years $\left(\overline{R Y_{p}}\right)$ selected the PC1 and PC3 factors into the linear model, which presented a significant model. The explained variance was as $\mathrm{R}^{2}=0.30(\mathrm{p}<0.05)$. The PCR for the mean relative yield of humid years $\left(\overline{R Y_{p}}\right)$ selected the $\mathrm{PC} 2$ and $\mathrm{PC} 3$ into the linear model, so the explained variance was $\mathrm{R}^{2}=0.40$ $(\mathrm{p}<0.01)$. The PCR for yield variability $\left(C V\left(R Y_{p}\right)\right)$ selected the PC1 and PC2 factors into the linear model. The explained variance was as $\mathrm{R}^{2}=0.41(\mathrm{p}<0.01)$. In droughty years, the sodification, salinization, soil texture, and nutrient contents determined the yields in our study. In humid years, the lower topographical position, the soil organic matter, and nutrient contents were the main limiting factors.

This multivariate approach is considered new in Hungary. In comparison with similar research in other regions, Shukla et al. (2004b) applied the same framework and reported that the grain yield $\left(\mathrm{R}^{2}=0.19, \mathrm{p}<0.02\right)$ and biomass yield $\left(\mathrm{R}^{2}=0.36, \mathrm{p}<0.003\right)$ were linearly correlated with four PCs derived. Mallarino et al. (1999) derived three common factors using factors analysis based on the covariance matrix of indicators. Their importance in explaining the yield variability differed greatly among cornfields, $\mathrm{R}^{2}$ were between $0.01(\mathrm{p}<0.254)$ and $0.67(\mathrm{p}<0.001)$.

\section{CONCLUSIONS}

1. The study demonstrated that the impact of soil properties on variability of grain yields depended on the weather over the years and the topographical position as well. In droughty years, the sodification, salinization, soil texture, and nutrient contents determined the yields, whereas 
in humid years the lower topographical position, the soil organic matter, and nutrient contents were the main limiting factors in our study.

2. Multivariate statistical methods are necessary to reveal the relationship between pedological parameters and crop yield in regard to weather conditions and topographical position. All pedological indicators that characterize the soil productivity function and major soil forming processes need to be included into the multivariate statistical analysis.

3. The advantages of using principal component regression analysis were as follows: (I) principal component analysis operates well with highly correlated variables and performs a reasonable dimension reduction; (II) principal components are uncorrelated and can express the interactions of soil properties. Although the principal components do not explain the total variance of the entire set of variables (which may be a disadvantage), they can explain the yields better than the simple indicators. Consequently, the variables can effectively explain the yield and the variability together with other variables as linear combinations.

\section{REFERENCES}

Ahman M.N. and Bhatti A.U., 2015. Comparison of regression models to predict potential yield of wheat from some measured soil properties. Pakistan J. Agric. Sci., 52(1), 239-257.

Andrews S.S. and Carrol C.R., 2001. Designing a soil quality assessment tool for sustainable agroecosystem management. Ecol. Appl., 11(6), 1573-1585.

Ayoubi S., Khormali F., and Sahrawat K.L., 2009. Relationship of barly biomass and grain yields to soil properties within a field in the arid region: Use of factor analysis. Acta. Agric. Scand. Section B-Soil Plant. Sci., 59(2), 107-117.

Brubaker S.C., Jones A.J., Frank K., and Lewis D.T., 1994. Regression models for estimating soil properties by landscape position. Soil Sci. Soc. Am. J., 58, 1763-1767.

Corwin D.L., Lesch S.M., Shouse P.J., Soppe R., and Ayars J.E., 2003. Identifying soil properties that influence cotton yield using soil sampling directed by apparent soilelectrical conductivity. Agron. J., 95(2), 352-364.

Cox M.S., Gerard D.P., Wardlaw M.C., and Abshire M.J., 2003. Variability of selected soil properties and their relationships with soybean yield. Soil Sci. Soc. Am. J., 67, 1296-1302.

Csathó P., 2003a. Nitrogen effects on yields of winter wheat (Triticum aestivum L.) in long-term experiments in Hungary (1960-2000) (in Hungarian). Növénytermelés, 52(1), 41-59.

Csathó P., 2003b. Nitrogen effects on yields of maize (Zea mays L.) in long-term experiments in Hungary (1960-2000) (in Hungarian). Agrokémia és Talajtan, 52(1-2), 169-184.

Csathó P., 2005. Potassium effects on yields of winter wheat (Triticum aestivum L.) in long-term experiments in Hungary (1960-2000) (in Hungarian). Növénytermelés, 54(3). 197-213.

de Araujo J.L., dos Anjos L.H.C., and Pereira M.G., 2009. Soil attributes and distinction of pedoenvironments for agriculture in the Mbya Indian Reserve in Ubatuba (in Spain). Brazilian J. Soil Sci., 33(6), 1765-1776.
Douaik A., Van Meirvenne M., and Toth T., 2007. Statistical methods for evaluating soil salinity spatial and temporal variability. Soil Sci. Soc. Am. J., 71(5), 1629-1635.

Egnér H., Riehm H., and Domingo W.R., 1960. Untersuchungen über die chemische Bodenanalyse als Grundlage für die Beurteilung des Nährstoffzustandes der Böden (in German). Ann. Royal Agricult. Coll. 26, Sweden, 199-215.

Fábián Á.P. and Matyasovszky I., 2010. Analysis of climate change in Hungary according to an extended Köppen classification system, 1971-2060. Quarterly J. Hungarian Meteorological Service, 114(4), 251-261.

FAO, 2014. World reference base for soil resources 2014. World Soil Resources Reports No. 106, FAO, Rome.

Govaerts B., Sayre K.D., and Deckers J., 2006. A minimum data set for soil quality assessment of wheat and maize cropping in the highlands of Mexico. Soil Till. Res., 87, 163-174.

Hargitai L., 1970. Determination of hydrolizable nitrogen content of several horticultural substrates (in Hungarian). Kertészeti Egyetem Közleményei, 34, 179-193.

Kaiser H.F., 1960. The application of electronic computers to factor analysis. Educ. Psychol. Meas., 29, 141-151.

Kononova M.M., 1966. Soil Organic Matter: its nature, its role in soil fonnation and in soil fertility. Pergamon Press, Oxford, UK

Mallarino A.P., Oyarzabal E.S., and Hinz P.N., 1999. Interpreting within-field realtionships between crop yields and soil and plant variables using factor analysis. Precis. Agric., 1, 15-25.

MSZ-08-0205/06, 1978. The analyses of physical and chemical soil properties. Hungarian Standard.

Németh T., 2006. Application of the Bray-Mitscherlich equation approach for economically and environmentally sound fertilization of field crops in Hungary. Comm. Soil Sci. Plant Anal., 37, 2227-2247.

Pálfai I., 2002. Probability of drought occurrence in Hungary. Quarterly J. Hungarian Meteorological Service, 106(3-4), 265-275.

Ping J.L., Green C.J., Bronson K.F., Zartman R.E., and Dobermann A., 2004. Identification of relationships between cotton yield, quality, and soil properties. Agron. J., 96(6), 1588-1597.

Rezaei S.A., Gilkes R.J., and Andrews S.S., 2006. A minimum data set for assessing soil quality in rangelands. Geoderma, 136, 229-234

Shukla M.K., Lal R., and Ebinger M., 2004a. Soil quality indicators for reclaimed minesoils in southeastern Ohio. Soil Sci., 169(2), 133-142.

Shukla M.K., Lal R., and Ebinger M., 2004b. Principal component analysis for predicting corn biomass and grain yields. Soil Sci., 169(3), 215-224.

Smith J.L., Halvorson J.J., and Papendick R.I., 1993. Using muliple-variable indicator kriging for evaluating soil quality. Soil Sci. Soc. Am. J., 57, 743-749.

Stenberg B., 1998. Soil attributes as predictors of crop production under standardized conditions. Biol. Fert. Soils, 27, 104-112.

Sys C., Van Ranst E., and Debaveye J., 1991. Land evaluation. Part 1. Principles in land evaluation and crop production calculations. General Administration for Development Cooperation, Agricultural Publication 7, Brussels, Belgium. 
Tittonell P., Sheperd K.D., Vanlauwe B., and Giller K.E., 2007. Unravelling the effects of soil and crop management on maize productivity in smallholder agricultural systems of western Kenya - An application of classification and regression tree analysis. Agric. Ecosys. Environ., 123, 137-150.

Tóth T., 2011. Evaluation of cropland productivity in Hungary with the D-e-Meter land evaluation system. Agrokémia és Talajtan, 60, 161-174.

Tóth T., Kuti L., Kabos L., and Pásztor L., 2001. Use of digitalized hydrogeological maps for evaluation of salt-affected soils of large areas. Arid Land Res. Manag., 15(4), 329-346.
Várallyay G., 2008. Extreme soil moisture regime as limiting factor of the plant's water uptake. Cereal Res. Comm., 36, 3-6.

Yao R., Yang J., Gao P., Zhang J., and Jin W., 2013. Determining minimum data set for soil quality assessment of typical saltaffected farmland in the coastal reclamation area. Soil Till. Res., 128, 137-148.

Zheng H., Chen L., Han X., Zhao X., and Ma Y., 2009. Classification and regression tree (CART) or analysis of soybean yield variability among fields in Northeast China: The importance of phosphorus application rates under drought conditions. Agric. Ecosys. Environ., 132, 98-105. 